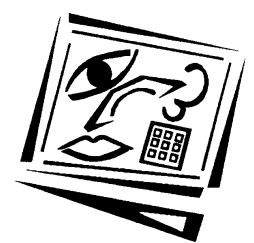

\title{
Student team projects in information systems development: Measuring collective creative efficacy
}

\author{
Hsiu-Hua Cheng \\ Chaoyang University of Technology, Taiwan \\ Heng-Li Yang \\ National Cheng-Chi University, Taiwan
}

\begin{abstract}
For information systems development project student teams, learning how to improve software development processes is an important training. Software process improvement is an outcome of a number of creative behaviours. Social cognitive theory states that the efficacy of judgment influences behaviours. This study explores the impact of three types of team knowledge: domain knowledge, methodological knowledge and implementation knowledge, as well as achievement motivation on student teams' collective creative efficacy (CCE) during information system development. This research also discusses the correlation between CCE and project performance using data from 98 student teams. Because of the difference in project characteristics, we divided the teams into "actual demand" project teams (having a real business case) and "suppositional demand" (having no real case, just an artificial or simulated case) project teams. The results show that achievement motivation positively influences CCE, either in "actual demand" teams or in "suppositional demand" teams. Domain knowledge is significantly correlated to CCE in "actual demand" teams, but methodological knowledge and implementation knowledge significantly influenced CCE in "suppositional demand" teams. CCE is not significantly related to project performance in "actual demand" teams. However, CCE is related to process performance and product performance in "suppositional demand" teams. Whilst this study explores issues in team project learning activities for students in information systems, some suggestions are made for educational designers using similar activities in other disciplines.
\end{abstract}

\section{Introduction}

In recent years, the software industry has grown quickly, creating a number of problems for software development, such as controlling costs, schedules and quality. Most software companies confront the problems of schedule delay, over budgeting and software management (Wang, Ju, Jiang \& Klein, 2008), but to maintain their competitive advantage, they must deliver high quality information systems under budget and on schedule to their customers (Solingen, 2004).

Software processes are the key to information system development (ISD) project performance. Coleman and O'Connor (2007) defined a software process as production steps to which software development companies should adhere, steps which would assist them in evaluating and measuring software quality. Paulk, Curtis, Chrissis and Bush (1993) defined software processes as activities, methods and practices which people can follow to develop and maintain information systems (IS) and related 
products, such as project plans, design documents, coding, test cases and manuals. Paulk, Curtis, Chrissis and Bush (2003) pointed out that improving software processes enhances software quality and production, while reducing the software development life cycle. On the other hand, following an unsuitable process may result in poor software framework and programs, high development costs, schedule delays or project failures (Jiang, Klein, Hwang, Huang \& Huang, 2004). Software companies adhering to an effective software process develop high quality software, within budget and on schedule (Green, Hevner \& Collin, 2005).

Fichman and Kemerer (1999) defined the innovation of a software process as any new way of developing software products; in other words, a change in IS team development techniques or methods. When ISD project teams propose new ways of executing development processes or when they improve the existing methods, ISD project performance can be increased. Most management information systems (MIS) departments in universities arrange project training courses of 2 to 3 semesters for developing an IS. The main goal of these courses is to develop the students' IS problem-solving ability. In ISD project training, student teams must use MIS knowledge and methods to develop an IS. This study tries to explore issues of software process improvement (process creativity) within ISD project teams. This research has defined creativity as student teams proposing new ideas or improving the established ways of executing software processes when developing an IS.

Social cognition theory states that self-efficacy/collective efficacy influence behaviour (Wang \& Wu, 2008; Park, 2009; Iskender \& Akin, 2010). In recent years, researchers have demonstrated that creative self-efficacy is important to creativity (Tierney \& Farmer, 2002). However, self-efficacy is individual level cognition, while efficacy at a team level is collective efficacy. Social cognition theory indicates that having teams with high collective efficacy results in good team performance (Bandura, 1997; Hsu, Chen, Chiu \& Ju, 2007). Thus, efficacy belief is an important element for exploring behaviour, performance and creativity.

Previous research has explored only the link between efficacy and creativity at an individual level. However, teams are the core units for organisational operations. Thus, this study has combined collective efficacy and creativity to propose collective creative efficacy (CCE). The CCE of a team refers to the shared belief in collaborating to develop creativity of process during information system development. In order to assist teachers in instructing students how to form CCE, this study has explored the influence of CCE in ISD student project teams.

\section{Theoretical background}

\section{Student teams and software processes}

Previous research into student teams and software processes has focused on the issues regarding the learning performance of students in a software process class, or their attitude to software processes. Rozman, Horvat and Rozman (2008) found that students were over-loaded in using software processes, because the modeling of software processes adopts capability maturity model integration (CMMI) in early stages during ISD. Lisack (2000) investigated the student attitude about personal software processes, and indicated that first year or second year college students were unable to recognise the benefit of software processes and thought that learning a software 
process decreased the time spent on the learning of a programming language. However, it was also stated that students who were interested in programming could recognise the benefits of personal software processes. Umphress, Hendrix and Cross (2002) reported a software engineering class in which students adopt software processes, and pointed out that these processes could describe the tasks which students must complete and bring the focus onto the creative tasks during ISD.

Accordingly, over-forcing students to learn a standardised software process might cause a negative attitude to a software process. However, a suitable software process can assist students in developing creativity during software development. Thus, educational units could teach a suitable software process to students and allow the student teams the flexibility to adjust their developing of processes and methods. As the issues of software process improvement for student teams have not been well explored, this study looks at the influence of collective creative efficacy of ISD student teams so as to assist educational units in providing the appropriate training.

\section{Creativity of information system development teams}

Oldham and Cummings (1996) defined creative results as being new, original, suitable and useful ideas or processes. Kurtzberg and Amabile (2001) pointed out that team creativity is a creative synthesis. Software development is a set of activities which include using information technology and methods to build software to solve organisational problems. In ISD teams, team members working on different aspects of a project combine individual outcomes or ideas into an IS. Thus, in this study, team creativity is evidenced in the team's new and useful ideas for improving a software process or their suggestions for a novel software process during an ISD project.

\section{Collective creative efficacy}

Bandura (1986) defined self-efficacy as people's judgments of their ability to organise and execute courses of action required to attain designated types of performances. Bandura (1997) further noted that efficacy views can be general or specific. Self-efficacy is a general belief (Chen, Gully \& Eden, 2001). In recent years, some scholars have extended self-efficacy to a specific area. Tierney and Farmer (2002) developed "specific" creative self-efficacy to describe judgments on an individual's ability to develop creativity. Tierney and Farmer (2002) defined creativity as a new and useful outcome in a domain; creative self-efficacy is a belief judgment about the ability to develop creativity. In our study, process creativity is new and useful software process improvement ideas.

Collective efficacy is a shared belief concerning a team's ability to organise and execute courses of actions required to achieve a specific outcome (Bandura, 1997). Collective efficacy is a general shared belief. To explore the development of creativity, this study has combined collective efficacy and creativity to propose collective creative efficacy. The collective creative efficacy of an ISD team refers to a shared belief in collaborating to develop creativity of process during software development.

\section{Key factors for improving software process}

Many studies have explored the key influences on software process improvement, which include employee support and participation (Dyba, 2005; Niazi, Wilson \& Zowghi, 2005), the time and resources of the employees involved (Niazi, Wilson \& 
Zowghi, 2005), the experience of the staff (Rainer \& Hall, 2002), and the accumulated knowledge and experience from successful projects (Xu \& Ramesh, 2008).

The experience and knowledge of team members are keys to the performance of software process improvement. However, student teams have only ISD knowledge learned in school, and have no practical experience. As students with strong achievement motivation spend many extra hours participating in software development, this study has explored the impact of team knowledge and achievement motivation on collective creative efficacy.

\section{Achievement motivation}

Murray (1938) indicated that achievement motivation was the desire to overcome difficulties, to quickly finish tasks, and to perform better than others. Chen (2008) defined achievement motivation as the desire to be outstanding, to be successful, to accomplish difficult tasks and to perform better than others. Helmreich and Spence (1978) saw achievement motivation as multi-dimensional including such aspects as mastery, work orientation, competitiveness and personal unconcern. Besides, previous studies indicated motivation was a key influence on creativity (Amabile, 1997; Tierney et al. 1999).

\section{ISD knowledge}

Barki, Rivard and Talbot (2001) pointed out that a software project team needs to have developing knowledge, application knowledge, task knowledge, generic knowledge and user experience. Lacking certain knowledge, ISD teams may face high project risks. Jiang, Klein, Van Slyke and Cheney (2003) indicated that the key knowledge for ISD members was technical/management knowledge and domain knowledge and skills.

Based on previous research and the context of ISD student teams, this study has proposed that ISD team knowledge should include:

1. Domain knowledge: consists of application knowledge, user knowledge and communication skills.

2. Methodological knowledge: consists of knowledge and skills about the methodology of system development and project management.

3. Implementation knowledge: consists of knowledge and skills about system analysis, system design and implementation.

\section{Research model and hypotheses}

Gibson and Earley (2007) suggested that team members' awareness of one another's information and knowledge formed the judgment of collective efficacy. Tierney and Farmer (2002) also indicated that knowledge was important in the shaping of creative self-efficacy. Studies of collective creativity (e.g. Amabile, 1997) have demonstrated that expertise is the key to the development of creativity. When teams have the knowledge, skills and abilities required to execute projects, team members can use their diverse views to search for solutions to their tasks and to develop creativity (Paulus, 2000). Thus, a team that perceives it has the knowledge required for the task 
has increased confidence in its ability to develop team creativity. Thus, this study has also explored the knowledge of ISD teams on developing CCE.

During developing an IS, student teams need to have domain, methodological and implementation knowledge to finish their ISD project, and they then find ways and methods of developing IS based on that knowledge. When teams own more complete knowledge, the members have faith in their own abilities and are better equipped to develop new methods or improvements to a software process.

ISD teams must go through several stages to finish their projects. These stages include understanding user demand, project analysis, system analysis and design, programming, testing and delivering IS to customers. Domain, methodological and implementation knowledge are essential for ISD. When team members own domain knowledge, they can easily communicate with the end users. Tierney and Farmer (2002) demonstrated a correlation between knowledge and creative self-efficacy. Gardner (1993) observed that domain knowledge influences creativity. Thus, teams with domain knowledge would believe they can adjust a system analysis and design process and will propose new ways to manage requirements. When teams have methodological knowledge, they are able to plan and control projects, and teams with better methodological knowledge have more confidence in their ability to find the defects in processes and to improve them. When teams have implementation knowledge, team members easily perceive they are able to improve methods of requirement analysis, system integration and system verification to develop IS. This study has therefore proposed hypotheses 1-3 as follows:

H1: Domain knowledge positively influences CCE in ISD teams.

H2: Methodological knowledge positively influences CCE in ISD teams.

H3: Implementation knowledge positively influences CCE in ISD teams.

Zander and Forward (1968) showed that team members with high achievement motivation will be more interested in team success. Kiliç-Çakmak (2010) indicated motivational factors can predict self-efficacy of e-learners. Chen et al. (2002) found that a team member's averaged achievement motivation was an important predictor of collective efficacy. Creativity research has also emphasised the importance of motivation for creativity (Amabile, 1997; Shalley \& Oldham, 1997). When there are many members with high achievement motivation in a team, the team has a strong drive to achieve team goals and believes they can achieve those goals.

Members with high achievement motivation strive for an outstanding performance and expect to do the task better than others. In ISD teams, members with high achievement motivation have a strong desire to adjust the existing development process so as to achieve a high level of performance. For example, members who are responsible for system analysis and design may make suggestions about management requirements in order to increase their work efficacy. Thus, when an ISD team has members with high achievement motivation, team members increase the judgment of CCE. This study has therefore proposed hypothesis 4 as follows:

H4: Achievement motivation positively influences CCE in ISD teams.

Accordingly, the proposed research model is shown in Figure 1. 


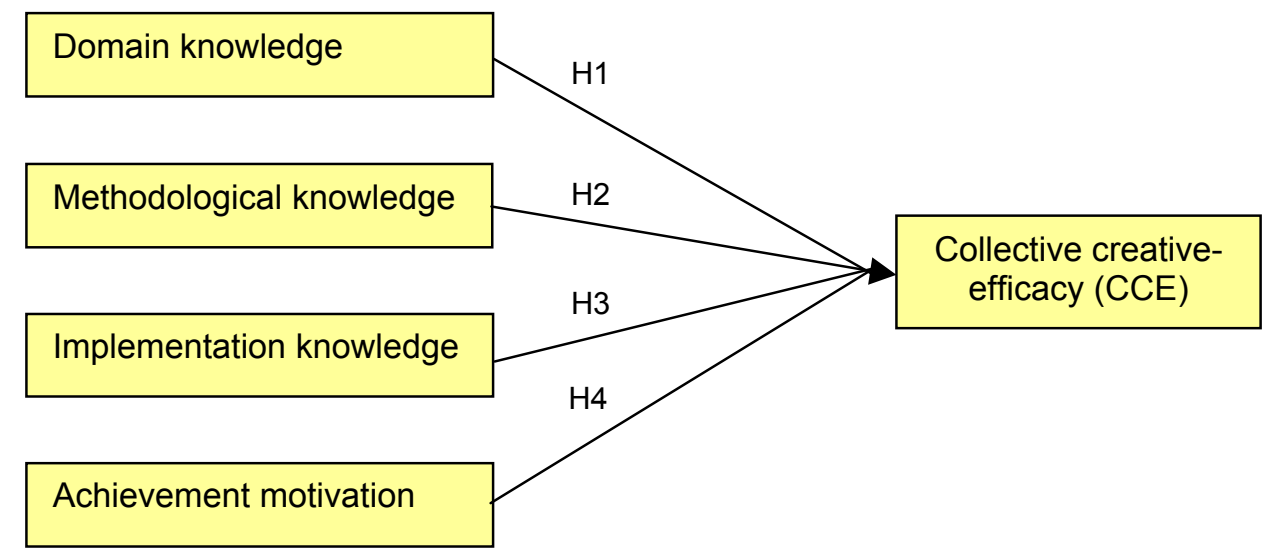

Figure 1: Research model

\section{Method}

\section{Subjects}

This study investigated student teams who attended an innovative contest conducted by the information services of colleges. The participating students came from all MIS departments of colleges in Taiwan. These teams had spent two or three semesters to develop their projects under the supervision of their teachers. Cooperating with the contest staff, we invited them to participate in our survey.

An influence of project characteristics on creativity efficacy is task (project) complexity (Tierney and Farmer, 2002). There are two types of projects. Some teams had user units to provide real system requirements for the development of IS projects. These teams are called "actual demand" project teams, i.e. having real business cases. This type of project would include many stakeholders, such as users, managers, project team members, and suppliers, thereby encountering a high project complexity (Xia \& Lee, 2005). Another type of project had no real case, just an artificial case. Those teams didn't face real users and instead visualised user demands for system requirements and functions. These teams are called "suppositional demand" project teams. There were 146 teams investigated. All members of the 101 project teams (484 members) completed the questionnaires. The response rate was $69 \%$. There were 38 "actual demand" teams and 60 "suppositional demand" teams. To verify the research model for the two types of projects, we also divided H1-H4 into H1a-H4a and H1b-H4b.

\section{Investigation procedures}

The questionnaires were emailed to students who attended the innovative contest and teachers who were advisers to the student teams. Each student was asked to complete a set of self-reported questionnaires including domain knowledge, methodological knowledge, implementation knowledge, achievement motivation and CCE. Also, in order to explore the criterion validity of CCE, each teacher was asked to complete a questionnaire about team performance. 


\section{Instrument}

We modified items which were drawn from Barki, Rivard and Talbot (2001) to develop items of domain, methodological and implementation knowledge. In the research of Barki, Rivard and Talbot (2001), the internal consistency reliability coefficient of ISD expertise was above 0.75 . We also modified achievement motivation items which were drawn from Chen (2008). In Chen's study, the reliability of achievement motivation was above 0.6. As collective creative efficacy is a new construct, there was not an existing questionnaire. This study combined the questionnaires of creative self-efficacy of Carmeli and Schaubroeck (2007) and the concept of collective efficacy to develop the measurement items of CCE. In the study of Carmeli and Schaubroeck (2007), the reliability of creative self-efficacy was 0.92 . All items of constructs were measured with 5-point Likert scale and shown in the Appendix.

\section{Data analysis and results}

The team-level effect of domain knowledge, methodological knowledge, implementation knowledge, achievement motivation and CCE was aggregated by averaging the scores of project members. Both between-group differences and withingroup agreement on the two measurements were examined to assess the aggregation suitability (James, Demaree \& Wolf, 1984; Chan, 1998). To verify between-group differences, this study calculated one-way ANOVA, and the results demonstrated statistical significance for domain knowledge, methodological knowledge, implementation knowledge, achievement motivation and CCE. An assessment of within-group inter-rater agreement $\left(\mathrm{r}_{\mathrm{wg}}\right)$ was calculated, as suggested by James, Demaree and Wolf (1984). The $r_{w g}$ coefficients of CCE for the 3 projects were below 0.7 (James, Demaree \& Wolf, 1984). We deleted data from these 3 teams to assure that the retained team data (98 teams, 468 members) were suitable to be aggregated.

\section{Reliability and validity}

This study used partial least squares to analyse our data. We assessed convergent validity by average variance extracted (AVE). Fornell and Larcker (1981) indicated that with AVE as a measure, a score of 0.5 indicated acceptability. The AVE of all the constructs was above the acceptability value. We verified the discriminant validity of our instrument by looking at the square root of AVE, as recommended by Fornell and Larcker (1981).

Table 1 presents the AVE, and square root of AVE of each construct and correlation among each construct. The results as shown in Table 1 confirmed the discriminant validity: the square root of the AVE for each construct was greater than the levels of correlation involving the construct (Chin, 1998).

Table 1: Cronbach's alpha coefficients, CR, AVE and correlations among constructs

\begin{tabular}{|l|c|c|c|c|c|c|c|c|}
\hline \multicolumn{1}{|c|}{ Construct } & $\begin{array}{c}\text { Cronbach's } \\
\text { alpha }\end{array}$ & CR & AVE & (1) & (2) & (3) & (4) & (5) \\
\hline (1) domain knowledge & 0.78 & 0.87 & 0.59 & 0.77 & & & & \\
\hline (2) methodological knowledge & 0.75 & 0.86 & 0.67 & 0.03 & 0.82 & & & \\
\hline (3) implementation knowledge & 0.74 & 0.81 & 0.58 & 0.09 & 0.03 & 0.76 & & \\
\hline (4) achievement motivation & 0.83 & 0.87 & 0.53 & $0.23^{*}$ & 0.16 & 0.17 & 0.73 & \\
\hline (5) CCE & 0.94 & 0.95 & 0.70 & $0.31^{*}$ & $0.37^{*}$ & $0.33^{*}$ & $0.39^{*}$ & 0.84 \\
\hline
\end{tabular}

\footnotetext{
${ }^{*}$ indicated $p<0.05$
} 
We also assessed reliability and internal consistency in the measurement model. Hair (1998) pointed out that the loadings of indicators must be above $0.3(p<0.05)$. The testing of loadings shows the consistency of indicators, and in this study all path loading of indicators was above $0.3(\mathrm{p}<0.05)$. This demonstrated that all constructs were valid. Besides, the Cronbach's $\alpha$ coefficient and value of composite reliability (CR) of all the constructs were above 0.7 (Nunnally, 1978). This result meant that all the constructs were reliable. The Cronbach's $\alpha$ coefficient and value of CR are shown in Table 1.

Furthermore, we explored the criterion validity of CCE. Research has indicated that CCE is one of the most important influences on performance (Akgun, Keskin, Byren \& Imamoglu, 2007). Thus, this research collected the process and product performance data of each ISD student team. Because we were unable to obtain objective data, we collected subjective data from the team teachers. All 98 teachers of the student teams responded to the questionnaires.

Items of process performance and product performance were developed based on items from Henderson and Lee (1992). An example item of product performance was, "The IS developed by your project team achieved the project target." An example item of process performance was, "Your project team completed the project tasks on schedule." The reliability of process performance and product performance in Henderson and Lee (1992) was above 0.7. In this research, the Cronbach's $\alpha$ coefficient of process performance was 0.90 ; the value for CR was 0.93 . The Cronbach's $\alpha$ coefficient of product performance was 0.85; the value for CR was 0.90. In "actual demand" teams, the correlation between CCE and process performance was 0.23 $(\mathrm{p}=0.17)$; the correlation between CCE and product performance was $0.18(\mathrm{p}=0.28)$. In "suppositional demand" teams, the correlation between CCE and process performance was $0.38(\mathrm{p}<0.05)$; the correlation between CCE and product performance was 0.27 ( $\mathrm{p}<0.05)$. Thus, the criterion validity for CCE in "suppositional demand" teams was satisfied.

\section{Hypotheses testing}

Actual demand teams

The proposed Hypotheses 1a-4a were tested, as shown in Table 2. The direct effects of domain knowledge and achievement motivation on CCE were $\beta=0.31(\mathrm{p}<0.05)$ and $\beta=0.29$ ( $p<0.05$ ), thus supporting H1a, whilst H4a. H2a and H3a were not supported. Domain knowledge and achievement motivation explained $28 \%$ of the variance of CCE.

Table 2: The results of "actual demand" teams

\begin{tabular}{|l|c|c|l|}
\hline \multicolumn{1}{|c|}{ Path } & $\beta$ coefficient & T-value & \multicolumn{1}{c|}{ Result } \\
\hline Domain knowledge $\rightarrow$ CCE & $0.31^{*}$ & 2.17 & H1a is supported. \\
\hline Methodological knowledge $\rightarrow$ CCE & 0.24 & 1.61 & H2a is not supported. \\
\hline Implementation knowledge $\rightarrow$ CCE & -0.07 & 0.45 & H3a is not supported. \\
\hline Achievement motivation $\rightarrow$ CCE & $0.29^{*}$ & 2.00 & H4a is supported. \\
\hline$*$
\end{tabular}

* indicated $p<0.05$.

Suppositional demand teams

The proposed Hypotheses $1 b-4 b$ were tested, as shown in Table 3 . The direct effects of methodological knowledge, implementation knowledge and achievement motivation 
on CCE were $\beta=0.37$ ( $p<0.05), \beta=0.46(p<0.05)$, and $\beta=0.30(p<0.05)$, thus supporting $\mathrm{H} 2 \mathrm{~b}, \mathrm{H} 3 \mathrm{~b}$ and $\mathrm{H} 4 \mathrm{~b}$. H1b was not supported. Methodological knowledge, implementation knowledge and achievement motivation explained $60 \%$ of the variance of CCE.

Table 3: The results of "suppositional demand" teams

\begin{tabular}{|l|c|c|l|}
\hline \multicolumn{1}{|c|}{ Path } & $\beta$ coefficient & T-value & \multicolumn{1}{c|}{ Result } \\
\hline Domain knowledge $\rightarrow$ CCE & 0.15 & 1.52 & H1b is not supported. \\
\hline Methodological knowledge $\rightarrow$ CCE & $0.37^{*}$ & 4.47 & H2b is supported. \\
\hline Implementation knowledge $\rightarrow$ CCE & $0.46^{*}$ & 5.07 & H3b is supported. \\
\hline Achievement motivation $\rightarrow$ CCE & $0.30^{*}$ & 3.31 & H4b is supported. \\
\hline
\end{tabular}

* indicated $p<0.05$.

\section{Discussion}

The subject of this study was student project teams. According to the source of system requirements, we divided the teams into "actual demand" teams and "suppositional demand" teams. There were some differences between the two kinds of teams. Analytical results indicated that, in both "actual demand" teams and "suppositional demand" teams, achievement motivation positively influenced CCE. Creativity research has shown there is an intrinsic motivation drive to develop creativity (Amabile, 1997). Murray (1938) indicated that achievement motivation was aspiring to overcome difficulties, to finish tasks quickly, and to be better than others. To ensure the quality of product and process, students with high achievement motivation took greater care with project tasks and goals and worked harder to complete tasks. For example, programmers with high achievement motivation positively search ways to transmit variables among programs and try many methods to transmit variables to increase system efficiency. When an ISD team has many students with high achievement motivation, team members observe that other members work hard and have the confidence to do the tasks to increase judgment about improving software processes.

The analytical results have shown that the impact of three kinds of team knowledge on CCE were different in the two kinds of teams. The main difference was from the sources of system requirement. Software development life cycles includes system requirement analysis, system design, coding and maintenance. Hooper and Hsia (1982) stated that system analysis included requirements judgment, requirements analysis and requirements communication. When ISD teams were unable to collect full and correct user requirements, either the developing costs increased or the IS did not satisfy the user. Thus, the result of system analysis was a key factor for developing IS (Telem, 1988).

In "actual demand" teams, there were real users to describe IS requirements. In these teams, system analysis meant ISD team members collaborated with users to collect and judge user requirements (Byrd, Crossick \& Zmud, 1992). In this situation, when a team possessed domain knowledge, team members collaborated effectively with users to judge, analyse and communicate requirements. ISD teams with domain knowledge clearly knew the inadequacies of a software process; the lack of domain knowledge can cause IS failure.

Compared with "actual demand" teams, in "suppositional demand" teams system requirements were planned by team members rather than user units. "Suppositional 
demand" teams were more careful about whether or not these suppositional requirements should be implemented. Thus, methodological knowledge and implementation knowledge positively influenced CCE in "suppositional demand" teams.

The criterion validity of CCE in the two types of team was also different. Although some research has indicated a high correlation between efficacy and learning performance (Lodewyk \& Winne, 2005), Bandura (1997) has stated that the characteristics of the tasks and the results of previous performance may moderate the relationship between the judgment of efficacy and behaviour (performance). The properties of the tasks for the two kinds of student teams were different. The "actual demand" team projects were highly complex, which meant the "actual demand" team members faced greater uncertainty from the different and dynamic technologies and user units. IS users were concerned with the usefulness and ease of use of IS, and didn't care about software process improvement. "Actual demand" teams had to confront un-analysable and unexpected projects because the user units were numerous and dynamic. The complex projects make it hard for "actual demand" teams with high CCE to produce satisfactory IS for IS users. In other words, there was not a significant relationship between CCE and performance in the "actual demand" teams. However, in the "suppositional demand" teams, software process improvement helped teams manage and control projects. The project complexity of "suppositional demand" teams was less than that of the "actual demand" teams. Thus, the criterion validity of CCE was satisfied in the "suppositional demand"teams.

Treffinger (1980) thought creative thinking activities could increase creative ability. The objective of project training was to combine basic theories to produce and to train the thinking, creating and executing abilities of students. In recent years, creativity has been crucial for business success, where IS becomes more and more important. Thus, one of educational objectives of MIS has been to train students learning how to develop IS to assist businesses to solve problems and obtain advantages. Creativity of ISD, software process improvement in this study, is a valued objective in educational training.

Every student project team had an instructor who acted as independent study advisor, system tester, and credit grader. According the results of this study, teachers could encourage students so as to increase their confidence of software process improvement during student project training. This could make students better able to recognise the limitations of a software process and find ways of improving the software to increase project performance. Based on the above analysis and discussion, some suggestions of this study are made for educational designers using similar activities:

1. For executing ISD, various types of knowledge are essential. However, in different project situations, teachers should emphasise different knowledge. When student teams develop real IS for businesses, teachers can focus on domain knowledge. Student teams with domain knowledge can have discussions with users and develop creative requirement management processes to increase their CCE. On the other hand, if there are no user units to provide system requirement, student teams can still develop suppositional requirements. Thus, teachers can strengthen methodological knowledge and implementation knowledge in those student teams to develop their creative ideas and to increase their CCE. 
2. Teachers might try to enhance student motivations by supportive information (Kim \& Keller, 2008) in order to improve their CCE.

3. Since the required knowledge and success criteria of two types of project are different, teachers should adopt suitable grading standards in accord with project characteristics.

\section{Conclusions and future research}

Previous research has explored issues of software process improvement in practical environments. This study has explored the training of IS persons from an educational viewpoint in order to understand the antecedents of CCE in ISD student teams. The results of this study can be applied to educational designers using similar activities in other disciplines.

The project teams of this study were "actual team", i.e., the interactions of members were face to face. However, with new information technologies available, students are able to collaborate to develop information systems by virtual interaction (such as Herrera \& Fuller, 2011). In this remote or distance environment, the interactions and communications among virtual team members differ from actual teams. The sharing and transferring of information, knowledge, or even emotion among members would be important. There might be different factors influencing creative efficacy. Future studies may explore how virtual teams or different interaction patterns influence CCE.

\section{References}

Akgun, A. E., Keskin, H., Byren, J. \& Imamoglu, S. Z. (2007). Antecedents and consequences of team potency in software development projects. Information and Management, 44, 646-656. http: / / dx.doi.org/10.1016/j.im.2007.08.001

Amabile, T. M. (1997). Motivating creativity in organizations: On doing what you love and loving what you do. California Management Review, 40(1), 39-58. http: / / cmr.berkeley.edu / search / articleDetail.aspx?article=3889

Bandura, A. (1986). Social foundations of thought and action: A social-cognitive theory. NJ: PrenticeHall Press.

Bandura, A. (1997). Self-efficacy: The exercise control. New York: Freeman.

Barki, H., Rivard, S. \& Talbot, J. (2001). An integrative contingency model of software project risk management. Journal of Management Information Systems, 17(4), 37-69. http: / / www.jmisweb.org/issues/Spring_2001/index.html

Byrd, T. A., Crossick, K. L. \& Zmud, R. W. (1992). A synthesis of research on requirements analysis and knowledge acquisition techniques. MIS Quarterly, 16(9), 117-138. http:// www.jstor.org/stable/249704

Carmeli, A. \& Schaubroeck, J. (2007). The influence of leaders' and other referents' normative expectations on individual involvement in creative work. The Leadership Quarterly, 35, 35-48. http: / / dx.doi.org/10.1016/j.leaqua.2006.11.001

Chan, D. (1998). Functional relations among constructs in the same content domain at different levels of analysis: a typology of composition models. Journal of Applied Psychology, 83, 234246. http:/ / dx.doi.org/10.1037/0021-9010.83.2.234

Chen, G., Gully, S. M. \& Eden, D. (2001). Validation of a new general self-efficacy scale. Organizational Research Methods, 4, 62-83. http: / / orm.sagepub.com/ content/4/1/62.short. 
Chen, G., Webber, S. S., Bliese, P. D., Mathieu, J. E., Payne, S. C., Born, D. H. \& Zaccaro, S. J. (2002). Simultaneous examination of the antecedents and consequences of efficacy beliefs at multiple levels of analysis. Human Performance, 15(4), 381-409. http: / / dx.doi.org/10.1207/S15327043HUP1504_05

Chen, L. H. (2008). Job satisfaction among information system (IS) personal. Computers in Human Behavior, 24, 105-118. http:/ / dx.doi.org/10.1016/j.chb.2007.01.012

Chin, W. W. (1998). Issues and opinion on structural equation modeling. MIS Quarterly, 22(1), vii-xvi. http: / / misq.org/ misq/ downloads/download/ editorial/314/ ?SID=kq7gcccm2jqj1 olv049jlv7cd2

Coleman, G. \& O'Connor, R. (2007). Using grounded theory to understand software process improvement: A study of Irish software product companies. Information and Software Technology, 49, 654-667. http:/ / dx.doi.org/10.1016/j.infsof.2007.02.011

Dyba, T. (2005). An empirical investigation of the key factors for success in software process improvement. IEEE Transactions on Software Engineering, 31, 410-424. http: / / dx.doi.org/10.1109/TSE.2005.53

Fichman, R. G. \& Kemerer, C. F. (1999). The illusory diffusion of innovation: An examination of assimilation gaps. Information Systems Research, 10(3), 255-275. http: / / dx.doi.org/10.1287/ isre.10.3.255

Fornell, C. \& Larcker, D. (1981). Evaluating structural equation models with unobservable variables and measurement error. Journal of Marketing Research, 18, 39-50. http: / / www.jstor.org/ stable/3151312

Gardner, H. (1993). Creating minds. New York: Basicbook.

Gibson, C. B. \& Earley, P. C. (2007). Collective cognition in action: Accumulation, interaction, examination, and accommodation in the development and operation of group efficacy beliefs in the workplace. Academy of Management Review, 32(2), 438-458. http: / / dx.doi.org/10.5465/AMR.2007.24351397

Green, G. C., Hevner, A. R. \& Collins, R. W. (2005). The impacts of quality and productivity perceptions on the use of software process improvement innovations. Information and Software Technology, 47, 543-553. http:/ / dx.doi.org/10.1016/j.infsof.2004.10.004

Hair, J. F., Anderson, R. E., Tatham, R. L. \& Black, W. C. (1998). Multivariate data analysis (5th ed.). New Jersey: Prentice-Hall, Inc.

Helmreich, R. L. \& Spence, J. T. (1978). Achievement motivation and scientific attainment. Personality and Social Psychology Bulletin, 4, 222-226. http: / / dx.doi.org/10.1177/014616727800400209

Henderson, J. C. \& Lee, S. (1992). Managing I/S design teams: A control theories perspective. Management Science, 38(6), 757-776. http:/ / www.jstor.org/ stable/ 2632340

Herrera, O. \& Fuller, D. A. (2011). Collaborative model for remote experimentation laboratories used by non-hierarchical distributed groups of engineering students. Australasian Journal of Educational Technology, 27(3), 428-445. http: / / www.ascilite.org.au/ ajet/ ajet27/ herrera.html

Hooper, J. W. \& Hsia, P. (1982). Scenario-based prototyping for requirements identification. ACM Sigsoft Software Engineering, 7(5), 88-93. http:/ / dx.doi.org/10.1145/1006258.1006275

Hsu, M. H., Chen, I. Y. L., Chiu, C. M. \& Ju, T. L. (2007), Exploring the antecedents of team performance in collaborative learning of computer software. Computers $\mathcal{E}$ Education, 48(4), 700-718. http:/ / dx.doi.org/10.1016/j.compedu.2005.04.018 
Iskender, M. \& Akin, A. (2010). Social self-efficacy, academic locus of control, and internet addiction. Computers $\mathcal{E}$ Education, 54(4), 1101-1106. http:/ / dx.doi.org/10.1016/j.compedu.2009.10.014

James, L. R., Demaree, R. G. \& Wolf, G. (1984). Estimating within-group interrater reliability with and without response bias. Journal of Applied Psychology, 69, 85-98. http: / / dx.doi.org/10.1037/0021-9010.69.1.85

Jiang, J. J., Klein, G., Hwang, H. G., Huang, J. \& Huang, J. (2004). An exploration of the relationship between software development process maturity and project performance. Information \& Management, 41(3), 279-288. http:/ / dx.doi.org/10.1016/S0378-7206(03)00052-1

Jiang, J. J., Klein, G., Van Slyke, C. \& Cheney, G. (2003). A note on interpersonal and communication skills for IS professionals: Evidence of positive influence. Decision Sciences, 34(4), 1-15. http: / / dx.doi.org/10.1111/j.1540-5414.2003.02546.x

Kiliç-Çakmak, E. (2010). Learning strategies and motivational factors predicting information literacy self-efficacy of e-learners. Australian Journal of Educational Technology, 26(2), 192-208. http: / / ascilite.org.au/ajet/ajet26/kilik-cakmak.html

Kim, C. M. \& Keller, J. M. (2008). Effects of motivational and volitional email messages (MVEM) with personal messages on undergraduate students' motivation, study habits and achievement. British Journal of Educational Technology, 39(1), 36-51. http: / / dx.doi.org/10.1111/j.1467-8535.2007.00701.x

Kurtzberg, T. R. \& Amabile, T. M. (2001). From Guilford to creative synergy: opening the black box of team level creativity. Creativity Research Journal, 13, 285-294. http: / / dx.doi.org/10.1207/S15326934CRJ1334_06

Lisack, S. (2000). The personal software process in the classroom: Student reactions (An experience report). Software Engineering Education E Training. Proceedings 13th Conference, 169175. http:/ / dx.doi.org/10.1109/CSEE.2000.827035

Lodewyk, K. R. \& Winne, P. H. (2005). Relations among the structure of learning tasks, achievement, and changes in self-efficacy in secondary students. Journal of Educational Psychology, 97(1), 3-12. http:/ / dx.doi.org/10.1037/0022-0663.97.1.3

Murray, H. A. (1938). Exploration in personality. New York: Oxford University Press.

Niazi, M., Wilson, D. \& Zowghi, D. (2005). A framework for assisting the design of effective software process improvement implementation strategies. The Journal of Systems $\mathcal{E}$ Software, 78, 204-222. http:/ / dx.doi.org/10.1016/j.jss.2004.09.001

Nunnally, J. C. (1978). Psychometric theory. New York: McGraw-Hill.

Oldham, G. R. \& Cummings, A. (1996). Employee creativity: Personal and contextual factors at work. Academy of Management Journal, 39, 607-634. http: / / dx.doi.org/10.2307/ 256657

Park, S. Y. (2009). An analysis of the technology acceptance model in understanding university students' behavioral intention to use e-learning. Educational Technology E Society, 12(3), 150162. http:/ / www.ifets.info/journals/12_3/14.pdf

Paulk, M. C., Curtis, B., Chrissis, M. \& Bush, M. (1993). Key practices of the capability maturity model, Version 1.1. Technical Report, CMU/SEI-93-TR-025. Pittsburgh. http: / / www.sei.cmu.edu/ reports / 93tr025.pdf

Paulus, P. B. (2000). Groups, teams and creativity: the creative potential of idea generating groups. Applied Psychology: An International Review, 49, 237-262. http:/ / dx.doi.org/10.1111/1464-0597.00013 
Rainer, A. \& Hall, T. (2002). Key success factors for implementing software process improvement: A maturity-based analysis. The Journal of Systems \& Software, 62, 71-84. http: / / dx.doi.org/10.1016/S0164-1212(01)00122-4

Rozman, T., Horvat, R. V. \& Rozman, I. (2008). Modeling the standard compliant software processes in the university environment. Business Process Management Journal, 14(1), 53-64. http: / / dx.doi.org/10.1108/14637150810849409

Shalley, C. E. \& Oldham, G. R. (1997). Competition and creative performance: Effects of competitor presence and visibility. Creativity Research Journal, 10, 337-345. http: / / dx.doi.org/10.1207/ s15326934crj1004_5

Solingen, R. (2004). Measuring the ROI of software process improvement. IEEE Software, 21(3), 32-38. http: / / dx.doi.org/10.1109/ MS.2004.1293070

Telem, M. (1988). Information requirements specification I: brainstorming collective decisionmaking approach. Information Processing and Management, 24(5), 549-557. http: / / dx.doi.org/10.1016/0306-4573(88)90024-6

Tierney, P. T. \& Farmer, S. M. (2002). Creative self-efficacy: Its potential antecedents and relationship to creative performance. Academy of Management Journal, 45(6), 1137-1148. http: / / dx.doi.org/10.2307/3069429

Tierney, P. T., Farmer, S. M. \& Graen, G. B. (1999). An examination of leadership and employee creativity: The relevance of traits and relationships. Personnel Psychology, 52, 591-620. http: / / dx.doi.org/10.1111/j.1744-6570.1999.tb00173.x

Treffinger, D. J. (1980). Creative learning: what is it, and why is it important? LTI Bulletin, May, 6-7.

Umphress, D. A., Hendrix, T. D. \& Cross, J. H. (2002). Software process in the classroom: The Capstone Project experience. IEEE Software, 19(5), 78-85.

http:/ / doi.ieeecomputersociety.org/10.1109/ MS.2002.1032858

Wang, E. T. G., Ju, P. H., Jiang, J. J. \& Klein, G. (2008). The effects of change control and management review on software flexibility and project performance. Information $\mathcal{E}$ Management, 45(7), 438-443. http:/ / dx.doi.org/10.1016/j.im.2008.05.003

Wang, S. L. \& Wu, P. Y. (2008). The role of feedback and self-efficacy on web-based learning: The social cognitive perspective. Computers $\mathcal{E}$ Education, 51(4), 1589-1598. http: / / dx.doi.org/10.1016/j.compedu.2008.03.004

Xia, W. \& Lee G. (2005). Complexity of information systems development projects: Conceptualization and measurement development. Journal of Management Information Systems, 22(1), 45-83.

http: / / misrc.umn.edu/workingpapers/fullpapers/2003/0341_110103.pdf

Xu, P. \& Ramesh, B. (2008). Impact of knowledge support on the performance of software process tailoring. Journal of Management Information Systems, 25(3), 277-314. http: / / dx.doi.org/ 10.2753/ MIS0742-1222250308

Zander, A. \& Forward, J. (1968). Position in group, achievement motivation, and group aspirations. Journal of Personality and Social Psychology, 8, 282-288. http: / / dx.doi.org/10.1037/ h0025595 


\section{Appendix}

\section{Items of the questionnaire}

Items of collective creative efficacy:

According to the cooperating experience, $I$ believe that our team

(1) Will creatively achieve most team goals that we set.

(2) Will complete difficult tasks creatively when our team confronts them.

(3) Will be able to adopt creative way to obtain results which are important to our team.

(4) Will succeed to achieve creative efforts when we make up our minds.

(5) Will overcome many challenges creatively.

(6) Will complete many different tasks creatively.

(7) Will have more creativity to finish most tasks than other teams.

(8) Will accomplish tasks creatively even when our team faces difficulty.

Items of domain knowledge:

Please evaluate our team's level of expertise in terms of the following:

(1) knowledge in the specific application area of this system (e.g., knowledge about bank industry ).

(2) customer organizational operations knowledge (e.g., knowledge about Citybank operations).

(3) expertise in developing this kind of the system (e.g., ERP knowledge).

(4) knowledge and skills of communication.

\section{Items of methodological knowledge:}

Please evaluate our team's level of expertise in terms of the following:

(1) knowledge about development methodology (e.g., UML or prototyping).

(2) knowledge about development support tools (e.g., CASE tool-power designer or rational rose).

(3) knowledge about project management and tools (e.g., PERT charts, Gantt diagrams).

Items of implementation knowledge:

(1) knowledge about system analysis and design (e.g., DFD or ER model).

(2) expertise in implementation tools (e.g., programming languages, database inquiry languages).

Items of achievement motivation:

(1) I would do the job that is more challenging and difficult, rather than the job which makes me more confident and relaxed.

(2) I like to work in the environment full of competition.

(3) I would like to endure temporary sacrifice for the exchange of possible long-term rewards.

(4) If I am not good at something, I would work hard till I can master it, rather give it up and do the job that I am probably not good at.

(5) Once I accept a job, I will insist on it.

(6) Perfectly finishing a job can generate the sense of satisfaction by itself.

Authors: Dr Hsiu-Hua Cheng, Assistant Professor, Department of Information Management, Chaoyang University of Technology, Taiwan

Email: hhcheng@cyut.edu.tw

Dr Heng-Li Yang (corresponding author), Professor, Department of Management Information Systems, National Cheng-Chi University, Taiwan Email: yanh@nccu.edu.tw

Please cite as: Cheng, H.-H. \& Yang, H.-L. (2011). Student team projects in information systems development: Measuring collective creative efficacy. Australasian Journal of Educational Technology, 27(6), 881-895.

http:/ / www.ascilite.org.au/ajet/ajet27/cheng.html 